\title{
人工内耳を装用させた自閉症スペクトラム障碍 及び重度知的障碍を伴う難聴児の発達経過
}

田中美郷 ${ }^{122}$ ，芦野聡子 ${ }^{11}$ ，小山由美 ${ }^{3)}$ ，吉田有子 ${ }^{1)}$ ，針谷しげ子 ${ }^{2)}$, 熊川孝三 ${ }^{4)}$ ，武田英彦 ${ }^{4)}$

${ }^{1)}$ 田中美郷教育研究所

2)神尾記念病院

3) 健貢会総合東京病院

${ }^{4)}$ 虎の門病院耳鼻咽喉科

要旨 : 新生児聴覚スクリーニングで難聴が疑われ，1歳頃より難聴が進行した自閉症スぺ クトラム障碍及び重度知的障碍を伴う難聴児に 3 歳11か月時人工内耳を装着させた。本児 は䆍学校へ入る前から手話を導入した言語教育を受けてきた。本児は現在 12 歳に達した が，現在のコミュニケーションは聴覚的言語理解は発達しつつあるものの言語表出は専ら 手話である。本児は一時期聴覚過敏症があって人工内耳を拒否するようになった。しかし 現在はこれを克服して人工内耳を常用している。本児は社会生活を送る上で必要な skill を実体験を重ねて身に付けつつある。これには両親の熱意はもちろん，地域社会のいろい ろな分野の機関や人々の支援があった。両親は我々のアドバイスにも耳を傾けて，各方面 に働きかけてこの体制を築いてきた。この努力の成果として, 言語発達も含めて社会的経 験も積んで本児になりに豊かに育ちつつある。

$$
\text { ーキーワードー }
$$

龍児，人工内耳，重度精神発達遅滞，自閉症スペクトラム障碍，言語教育

\section{はじめに}

人間は言語を思考の道具とし，コミュニケーショ ンの手段としているが，しかしコミュニケーション は言語によらずとも可能であり，むしろ二者間の対 話では, ことばによって伝えられるメッセージは, 全体の35パーセントに過ぎず，残り65パーセントは ことば以外の手段によって伝えられるという説もあ る1”。た Montessori ${ }^{2}$ は, 我々は子どもの魂の中 に眠っている人間に呼びかける方法を知らねばなら ないと述べているが，コミュニケーションの根本は まさにこの点にある。これは発達の初期段階にある 乳幼児や心身障碍児の療育に当って特に重視される 点で，筆者らはかかる認識に基づいて聴覚障碍児の 早期の療育支援を続けてきた。ここで重視されるの
は五感を介するコミュニケーションであるが, 中で も聴覚はこれに障碍があると音声によるコミュニケ ーションは妨げられ, 言語発達が阻害されるといっ た独特な側面を有する。この問題に関し，我々は自 閉症スペクトラム障碍及び重度知的障碍に重度難聴 を合併する 1 例を乳児期から 12 年間療育支援を続 け，この間に人工内耳を装着させて見るべき成果を 得てきたのでその経緯を報告する。

\section{症例}

12歳男児。初診：平成12年11月28日（生後28日）。 現在の診断 : 両側重度感音難聴, 右網膜欠損症, 重 度知的障碍，自閉症スペクトラム障碍（ASD）

家族歴：両親と本児の 3 人家族。両親は共働き。 現病歴：出生時体重 $2944 \mathrm{~g}$ 。新生児聴覚スクリー 
ニング（NHS）で両耳 refer と言われ，精査と対策 を求めて来院。

初診時検査所見: 閉眼時, Infant Audiometer (Rion 製) で $1 \mathrm{kHz}$ warble tone $70 \mathrm{~dB}$ に無反応， 80 $\mathrm{dB}$ で泣き出す。木魚や小太鼓の大き目の音に驚愕 反射出現。すなわち高度難聴はないとしても中等度 ないしそれ以下の難聴は否定できないため, 家族支 援を続けながら behavioral audiometry 及び聴覚発

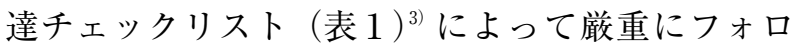
ーしてきた。

\section{支援方法}

本児の家族支援に当って当初我々が重きを置いて きた点は

1）親子のコミュニケーションの円滑化と情緒の 安定

2）このためには，最初は難聴の有無にかかわら ず五感を介してのコミュニケーションを重視し，難 聴の程度確認に努めながら聴覚活用に加えて子ども の発達に応じてべビーサインやジェスチャー, さら には手話なども活用する。

3）家庭生活はもち万ん大自然や社会生活におい て，子どもの発達にとって必要な実体験の機会を豊 かに作ってやる。

4）このためには地域社会における社会資源を極 力活用する。

5）この前提に立って，先々聾学校の教育に協力 して言語発達支援を続ける。

両親は仕事を有しながらも，わが子のために地域 社会の関係分野に積極的に働きかけて良き支援体制 を築いてきた。

\section{経過}

定期的外来訪問の折，保護者からは本児の日常生 活における様子を，また就学後は学校生活や学外で の活動などの報告を受け，更には担任からの報告及 び保護者と担任との交換日記などを通じて本児の発 達を追跡し，その都度本児にとって必要ないし有意 義と思われる提言をしてきた。かくして今日に至る までの経過の概略は以下の如くである。

1) 人工内耳 $(\mathrm{CI})$ 装着（3歳11カ月）まで
$0: 4$ (生後 4 カ月)。クリックに対する $\mathrm{ABR}$ 閾値 は右 $80 \mathrm{dBnHL}$ ，左 $70 \mathrm{dBnHL}$ 。睡眠時の音場におけ る聴性反射は 500 及び $1000 \mathrm{~Hz}$ warble tone に $60 \mathrm{~dB}$ で，2000 及び $4000 \mathrm{~Hz}$ 音には $70 \mathrm{~dB}$ で覚醒反射出 現。日常生活ではTVの音に泣き止むとのこと。

$0: 10$ 。親の声に振り向くことが多くなり, 発声 が活発になった。運動発達に遅れがあり，支えて立 たせようとすると嫌がって足をちぢめ，仰向けにす ると, 手足は動かすものの這わない。食物を手渡す と放り投げる。クリックに対する ABR 闇值は右 65 $\mathrm{dBnHL}$, 左 $75 \mathrm{dBnHL}$ 。

$1: 0$ 。ずり這いが活発になり，つかまり立ちをし ようとする傾向が出てきた。最近ニコニコ笑うよう になり，手持ちテープレコーダーから流れる童謡に 反応して音源を探す。外出して子どもが見えると喜 び，バイバイと手を振る。COR (conditioned orientation reflex）テストでは裸耳の反応閾值は平均 35 $\mathrm{dB}$ 。

$1: 6$ 。COR 閾値は $75 \mathrm{~dB}$ ，太鼓や木魚には強く吒 かないと振り向かないので, 難聴は進行してきたと 考え，ホームトレーニングプログラム (home training program; HTP) に参加してもらい, 補聴器 (hearing aid；HA）装用指導開始。伝い歩きする が，行動はマイペース。視線が合い難い。

$2: 0$ 。独り歩きが可能になった。HTP 参加後は保 育園に入れながら地元の言語聴覚士（ST）の協力 も得て指導を受けている。HA を右に着けた方が反 応はよく，話しかけると口元を見るようになった。 $\mathrm{COR}$ 間值は平均 $90 \mathrm{~dB}$ 。

$2: 3$ 。HAが着けられるようになった。保育園の 先生によると，HAを着けた方が反応はよい。周囲 に関心が出てきて何か真似ようとする傾向が出てき た。指示には従えないが，「ごはんだよ」「おふろた よ」というと分かるようだ。昨夏海に行った折の写 真をみせると，何か思い出すようであった。太鼓を 自分で吒く。

$2: 6$ 。保育園とSTの両方に連れていくに当っ て，母親の職場は協力的。寝る前に本を読むよとい うとやってくる。“おわり”を身振りで表現する。 ミッキーマウスに興味があり，絵と人形をマッチさ せるようになった。親が話かけると口元を見るよう になったが，行動はマイペースで，落ち着きなく勝 
表 1 乳児の聴覚発達チェックリスト

\begin{tabular}{|c|c|c|}
\hline 月齢 & 番号 & 項 \\
\hline \multirow[t]{3}{*}{0 力月児 } & 1 & 突然の音にビクッとする（Moro 反射） \\
\hline & 2 & 突然の音に眼瞼がギュッと閉じる（眼瞼反射） \\
\hline & 3 & 眠っているときに突然大きな音がすると眼瞼が開く（覚醒反射） \\
\hline \multirow[t]{5}{*}{1 力月览 } & 4 & 突然の音にビクッとして手足を伸ばす \\
\hline & 5 & 眠っていて突然の音に眼を覚ますか, または泣き出す。 \\
\hline & 6 & 眼が開いているときに急に大きな音がすると眼瞼が閉じる \\
\hline & 7 & 泣いているとき, または動いているとき声をかけると, 泣き止むかまたは動作を止める \\
\hline & 8 & 近くで声をかける（またはガラガラを鳴らす）と, ゆっくり顔を向けることがある \\
\hline \multirow[t]{3}{*}{2 力月览 } & 9 & 眠っていて，急に鋭い音がすると，ピクッと手足を動かしたり，まばたきしたりする \\
\hline & 10 & 眠っていて, 子供の騒ぐ声や, くしゃみ, 時計の音, 掃除機などの音に眼をさます \\
\hline & 11 & 話しかけると, アーとかウーとか声を出して喜ぶ（またはにこにこする） \\
\hline \multirow[t]{3}{*}{3 カ月児 } & 12 & 眠っていて突然音がすると眼瞼をピクッとさせたり, 指を動かすが, 全身がびくっとなることはほとんどない \\
\hline & 13 & ラジオの音, テレビのスイッチの音, コマーシャルなどに顔（または眼）を向けることがある \\
\hline & 14 & 怒った声や, やさしい声, 歌, 音楽などに不安そうな表情をしたり，喜んだり，または嫌がったりする。 \\
\hline \multirow[t]{4}{*}{4 力月児 } & 15 & 日常のいろいろな音（玩具, テレビの音, 楽器音, 戸の開閉など）に関心を示す（振り向く） \\
\hline & 16 & 名を呼ぶとゆっくりではあるが顔を向ける \\
\hline & 17 & 人の声（とくに聞きなれた母親の声）に振り向く \\
\hline & 18 & 不意の音や聞きなれない音, 珍しい音に, はっきり顔を向ける \\
\hline \multirow[t]{3}{*}{5 カ月览 } & 19 & 耳もとに目覚し時計を近づけると, コチコチいう音に振り向く \\
\hline & 20 & 父母や人の声，録音された自分の声など，よく聞き分ける \\
\hline & 21 & 突然の大きな音に, びっくりしてしがみついたり, 泣き出したりする \\
\hline \multirow{3}{*}{6 力月児 } & 22 & 話しかけたり歌をうたってあげたりすると, じっと顔を見ている \\
\hline & 23 & 声をかけると意図的にサッと振り向く \\
\hline & 24 & テレビやラジオの音に敏感に振り向く \\
\hline \multirow[t]{4}{*}{7 力月览 } & 25 & 隣の部屋の物音や, 外の動物の鳴き声などに振り向く \\
\hline & 26 & 話しかけたり歌を歌ってあげたりすると, じっと口もとを見つめ, ときに声を出して答える \\
\hline & 27 & テレビのコマーシャルや, 番組のテーマ音楽の変わり目にパッと向く \\
\hline & 28 & 叱った声（メッ！ コラッ！ など）や, 近くで鳴る突然の音に驚く（または泣き出す） \\
\hline \multirow[t]{4}{*}{8 力月览 } & 29 & 動物の鳴き声をまねるとキャッキャッいって喜ぶ \\
\hline & 30 & 機嫌良く声をだしているとき, まねてあげると, またそれをまねて声を出す \\
\hline & 31 & ダメッ！ コラッ！ などというと, 手を引っ込めたり, 泣き出したりする \\
\hline & 32 & 耳もとに小さな音（時計のコチコチ音など）を近づけると振り向く \\
\hline \multirow[t]{5}{*}{9 力月览 } & 33 & 外のいろいろな音(車の音, 雨の音, 飛行機の音など)に関心を示す(音のほうにはってゆく, または見まわす) \\
\hline & 34 & 「オイデ」,「バイバイ」などの人のことば（身振りを入れずにことばだけで命じて）に応じて行動する \\
\hline & 35 & 隣の部屋でもの音をたてたり, 遠くから名を呼ぶとはってくる \\
\hline & 36 & 音楽や, 歌を歌ってあげると, 手足を動かして喜ぶ \\
\hline & 37 & ちょっとしたもの音や, ちょっとでも変わった音がするとハッと向く \\
\hline \multirow[t]{2}{*}{ 10カ月児 } & 38 & 「ママ」,「マンマ」または「ネンネ」など, 人のことばをまねて言う \\
\hline & 39 & 気づかれぬようにして, そっと近づいて, ささやき声で名前を呼ぶと振り向く \\
\hline \multirow[t]{4}{*}{ 11力月児 } & 40 & 音楽のリズムに合わせて身体を動かす \\
\hline & 41 & 「○○チョウダイ」と言うと, そのものを手渡す \\
\hline & 42 & 「○○ドコ?」と聞くと, そちらを見る \\
\hline & 43 & 隣の部屋でもの音がすると, 不思議がって, 耳を傾けたり, あるいは合図して教える \\
\hline \multirow{2}{*}{$\begin{array}{c}12 \sim 15 \\
\text { 力月児 }\end{array}$} & 44 & 簡単なことばによる言いつけや要求に応じて行動する \\
\hline & 45 & 目，耳，口，その他の身体部位をたずねると, 指をさす \\
\hline
\end{tabular}


手に動きまわる。難聴は一層進行し, 人工内耳 (cochlear implant；CI) を考慮することにした。加 えて䆍学校の支援も受けることを勧めた。

$3: 3$ 。聾学校では，こころで感じる先生とうわべ だけでみてしまう先生では, 子どもは敏感に反応し てしまうとのこと（コミュニケーションの核心をな すものはこころと言われ，Montessori ${ }^{2}$ が療育にお いて重視したのもこの点にある)。自己中心的行動 は著しいが，CIのための検査入院は独りででき た。保育園へは喜んで通っている。

$3: 6$ 。聾学校では手話と指文字を使っている。担 任はことばでなく意味を教える先生で，本児はよく なついている。絵本を集中してみている。HAを着 けるとアーアー声を出す。

$3: 9$ 。少しジェスチャーをするようになった。難 聴は更に進行し，HAを着けても反応しなくなっ た。

ここに至るまでの behavioral audiometry の閾值 の推移を図 1 に，またCI を装着して 8 歳までの聴 覚発達経過を図 2 に示した。図 3 は11歳時の純音才 ージオグラムと CI 装用䦔值である。

2) CI 装着から就学まで

$3: 11$ 。左耳に CI 装着。

$4: 2$ ○I が外れると着けたがる。TVの音にびっ くりした。機嫌がいいとずーっと声を出している。 手話でオシッコ，チョーダイ，オイシイネなどを表 現するようになった。模倣やゴッコ遊びが増えてき た。視覚に入ったものと聴覚情報との結びっきがで

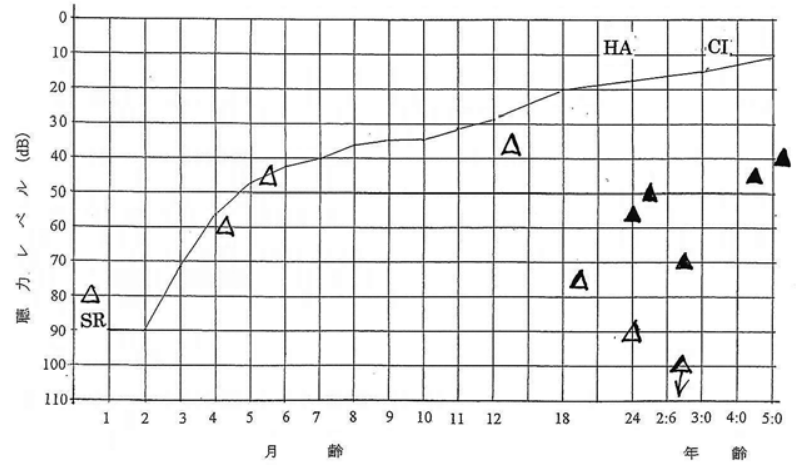

図 1 Behavioral audiometry（BOA，CORなど）の反応閾 值 $(\triangle)$ 及び補聴器または人工内耳の装用閾値 $(\boldsymbol{\Delta})$ （いずれも四分法平均）の発達経過。図中の曲線は健 聴乳幼児の反応閾值発達曲線（Kaga and Tanaka 10)）
きてきている（両親の供述）。行動は相変わらずマ イペース。

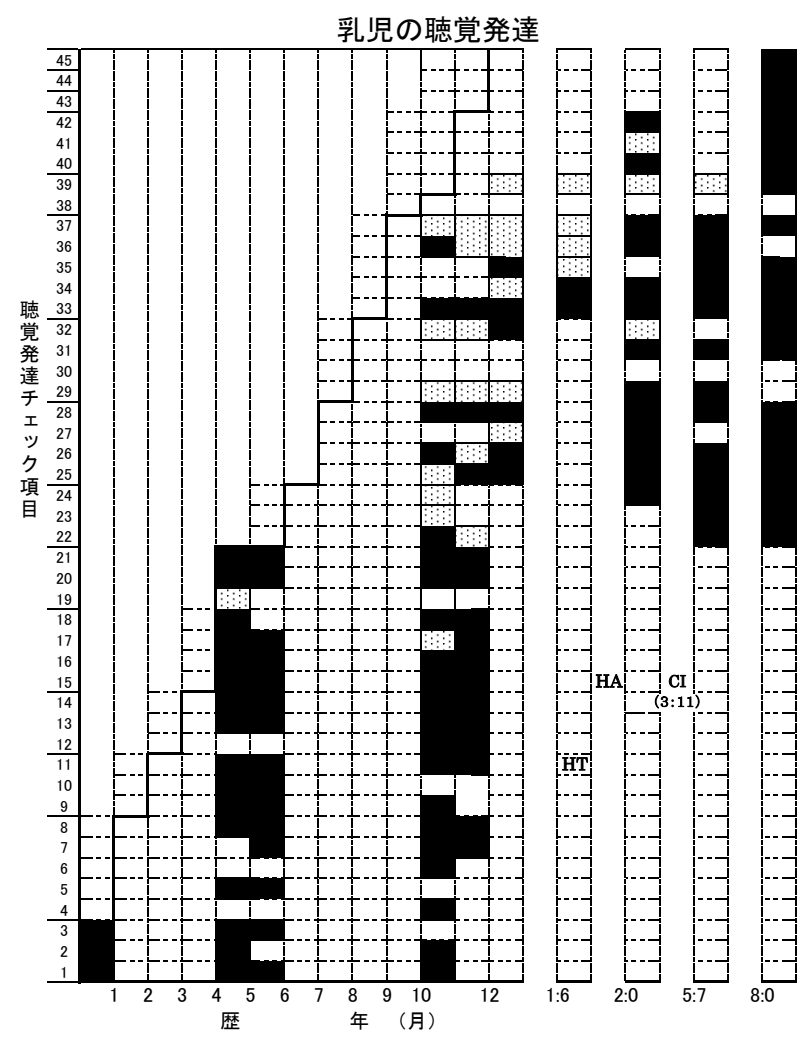

図2 乳児の聴覚発達チェックリスト（田中, 進藤, 他 3)）でみる聴覚発達経過。

縦軸の番号はチェック項目番号。黒い部分は反応の 明確な項目で, 点々の部分は時々反応のみられた項 目。HT はホームトレーニング参加時点。

HA 及び CI はそれぞれ補聴器及び人工内耳装着時点。

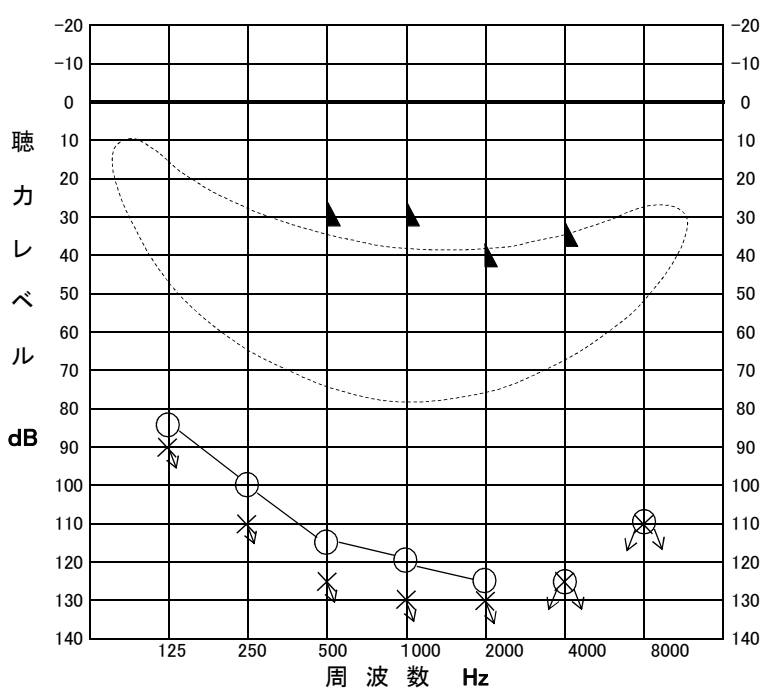

図３１1歳時の純音聴力及び CI 装用閾值 
$4: 5$ 。CD ショップでの騒音を嫌う（聴覚過敏症 の出現)。トイレの水洗音にびっくりした。電車の 音がすると空を見上げていた。名を呼ぶと振り向 く。いたずらしてコラッ！というとびっくりした。

$4: 6$ 。テープから流れる音楽（童謡）に少しリズ ムを取る。呼び出しのブザー音を嫌い，ドアが開い ていると気になって閉めに行く。魚に興味が出てき た。

$4: 10$ 。名を呼ぶと反応するようになった。壟学 校夏休み中保育園へ喜んで行っていた。始め子ども のうるさい声にびっくりしていた。パパ, ママ, ジ ーチャンと言えば分る。マラカス, タンブリンを勝 手に鳴らす。

$5: 0$ 。ニコニコして診察室に入室するなり, 我々 の背後にある玩具棚に突進。最近ジェスチャーや手 話にやっと興味が出てきたとのこと。意思表示には 指差して声を発する。“いや”と発するようになっ た（果物が大嫌い）。聾学校では担任とコミュニケ ーションが取れるようになった。音楽はディズニー の曲が好き。

$5: 3$ 。名を呼んで機嫌がいいと「ハイ」と返事を する。手話でコミュニケーションが取れつつある。

$5: 7$ 。人見知りする。䆍学校では手話に指文字も 加えて真似するようになってきた。食事は箸を使っ て自分で食べる。CI を家に帰ると外してしまう。

$5: 8$ 。コードの断線で CI をしばらく外していた ところ, 装着を拒否するようになった。電流を下げ て徐々に上げつつあるが, 最近は嫌がらなくなっ た。玩具を手にしてヒラヒラ常同的に振る。呼んで 返事をしなくなった。

$6: 0$ 。身体が大きくなり，体力が増して手がかか るようになった。音楽を聴き分け, TVの幼児番組 の音楽を好むようだ。自己中心的な行動は相変わら ずであるが，集中力は随分出てきた。初対面の人を 気にする。最近子どもの集団に参加できるようにな ってきた。物を渡して「ポイしてきて」「ドアを閉 めて」「電気を消して」「おじいちゃんに渡してき て」などはことばだけでできる。空を飛んでいる飛 行機の音を聴いて空を指す。自分の名の最初の部分 を指文字で表わすようになった。

$6: 3$ 。母親が「オ八ヨウゴザイマス」と促すと, それらしく声を出して言う。指文字を真似る。エレ
ベーターの最初の “エ”, 自分の名や友達の名は頭 の一文字を指文字で表す。“好き”“食べたい”“開 けて”“やって”などを手話で表現し，声を出して 口形を真似るようになった。学校で友達と取り合い をするようになった。公園で同年齢の子どもに近づ いていく。

\section{3）就学後}

$6: 4$ 。䆍学校小学部 1 年生になった。音楽が好 き。ただし学校での音楽の時間は飽きてしまう。手 話や指文字をかなり覚えた。“死んだ”“悲しい”も 分かってきたようだ。金魚をひねりつぶし，お墓を 作ってナンマイとやっていた。聾学校を終えて NPO の某集団に参加しているが，そこでは結構こ とばが通じると言われている。朝「○○へ行くよ」 というと喜んでいる。書いた文字（平仮名）は自分 の名や友達の名位は分かる。

6:9。手話で “今日は”とやりながら入室。落着 きがかなり出てきた。ことばが大分通じるようにな り，NPO の施設の人に手話よりことばの方が通じ 易くなってきたと言われた。CI を取ると自分から 着けたがる。

$6: 11$ 。聾学校から帰って祖父母のところへ行く と，疲れたといって CI を外す。なに?と問うと答 えるようになった。色の名や数は10位までであれ ば，手話でできる。最近は信号機の色の意味が分か って，赤で止まって待っている。年上の子に気配り しながら行動できるようになってきた。人の顔が描 けるようになった。“ブランコ押して”と友達に指 文字で要求していた。

$7: 3$ 。遊戯聴力検査によって左右別々に聴力測定 が可能になった。自己中心的な行動は未だみられる が，診察室で両親の脇で椅子に座っておれるように なった。CIは家でリラックスしているときは外す が，外出先で音が聞こえないと不安がって着ける。 都合の悪いときは聞こえないふりをする。

$7: 5$ 。䆍学校 2 年生になった。会話は口話だけで 通じることが多くなった。知らないことばについて は，壟学校の先生も手話とことばを併せて使ってく れる。手話の本を持ってきて自分でも練習してい る。聾学校の寄宿舎に入れた。50名位子どもがいて 楽しいようだ。数字は30位は数えるとのこと。 
$7: 9$ 。夏休みで祖父母と一緒に生活し，平仮名と 書き取り及び指文字の練習をした。「冷蔵庫にアイ スあるよ。1本持ってきて」はことばで言ってでき る。話しかけて本児から返ってくるのは主として手 話。自分で作った手話（例えば尺取り虫）もある。

8：0。聾学校の担任が代わった。自分から先生に 手話や指文字を要求。絵本をみて手話で少し説明し てくれるようになった（“同じ”など）。某大学手話 サークルの社会福祉系学生（壟学校の先輩）が家庭 教師にきてくれる。兄のような感じで大変喜んでつ いて行く。今片仮名を覚えつつある。両親は共働き ながらも担任と連絡帳も活用し合って本児の教育に 励んでいる。

$8: 3$ 。朝起きると，先ずTVをつける。ニュー ス，天気，うらないなどの番組を視る。自分の名前 の “か”が画面に出ると興奮して喜ぶ。自分から指 差して“みて! みて!”とやる。指文字と平仮名の マッチング練習をしている。指文字が速くなった。

$8: 5$ 。聾学校 3 年生。マイペースな面はあるもの の，落着が一段と出てきて視線も合うようになって きた。トイレの水洗音, 電気掃除機の音, 精米機の 騒音にCI を外す。4月からまた寄宿舎に入った。 喜んでいる。上級生が迎えにきてくれる。指文字を 自ら使っている。親との会話がかなりできるように なった。手をヒラヒラ動かしたり，足をバ夕バ夕さ せるのは相変わらず。

$8: 11$ 。入室するなり我々の背後にある玩具に向 かう。自分の意思を絵で示そうとする。ただし横断 歩道を描いて人の絵が描けないので, “人”と書い ていた。トイレに入るときはCIを外し，掃除機を 使抢うとすると逃げていく。計算は簡単なものはで きる。色名は分かっているものの，微妙な色のとき は困っている。野菜を食べるようになった。自分の 頭を吒く，発声しながら手をヒラヒラ動かすなど, 常同行為は相変わらず。

$8: 11$ 。子どもに関心が出てきて, 公園などで子 どもに近づいていく。手話で話しかけるが相手に通 じない。聴覚を介してのことばの理解はずい分発達 し，たとえば「脱いだ靴下を洗濯機に入れてきて」 というとできる。しかし本人の表出はほとんど手 話。学校が大好きで，たまにウィークディが休日に なっても行きたがり，学校まで行って門が閉じてい
るのを見るまでは納得しない。

本児の住む $\mathrm{S}$ 市には 4 年前に聴覚障碍児の集団の “S クラブ”が誕生した。壟学校を借りて地元のボ ランティアが立ち上げたクラブで，壟学校の教員や 大学の社会福祉系学生, 襲学校の卒業生, 難聴児な どもいて，本児もこれに参加して喜んで遊んでい る。

DVD を視て泣いているシーン, 怖いシーンが出 ると“泣いている”“怖い”と手話で表現する。気 に入ったものがあると指差すが，「これ何？」の質 問はない。

$9: 3$ 。入室の際母親に「おはようございます」と 促されると，天井を見ながら手話で挨拶。その後直 ちに玩具棚へ向かい，怪獣の玩具を二つ手に持って ヒラヒラ振る。 3 カ月前より, 我々のアドバイスに 応じて地域の某先生の自閉症児集団に参加してい る。手を出してちょっかいする子どもがいるが，し ようがないなという感じでついていく。1 月月前よ り聾学校の「纬帚り会」で，寄宿舎に行きたがって 帰ろうとせず大騒ぎになった。CI を使っていても 最近は聞こえないふりをしたり，聞きたくなければ コイルを外して逃げる。“今日”“明日”“3 時”な どの時間観念が発達してきたようだ。自ら許可を求 めるとか, 意思表示の行動も見られるようになっ た。

$9: 6$ 。䆍学校 4 年生。文字を見て書く。落着いて 絵本を独りで見ている。動物や魚の絵が好きで, 書 棚から探してくる。“すっぱい”“甘い”“からい” を手話で表現するようになった。

$9: 9$ 。片名を書く。片仮名と平仮名を一応マッチ させるが，まだ不確実。紙と鉛筆を渡すと 4 歳児レ ベルの人の絵を描いた（図 4 参照)。音楽は好きで 手話ダンスを好む。口唇図を見て声も出せるように なった。手話で 2 語文表出。本児からの質問はまた 見られないが，こちらの質問には手話で答える。好 きな魚 “鮎” “鯛”は指文字で表現することがある。 道順を覚えるとごまかしがきかない。

$10: 0$ 。地域のマラソン大会に出て，1.5km を元 気に走り抜いた。CI は嫌がらないが，時に聞こえ ないふりをする。いたずらをするときは外してい る。掃除機の音にはなれてきたが，トイレに入ると きは外して，出てくると着ける。海へ行った。魚を 

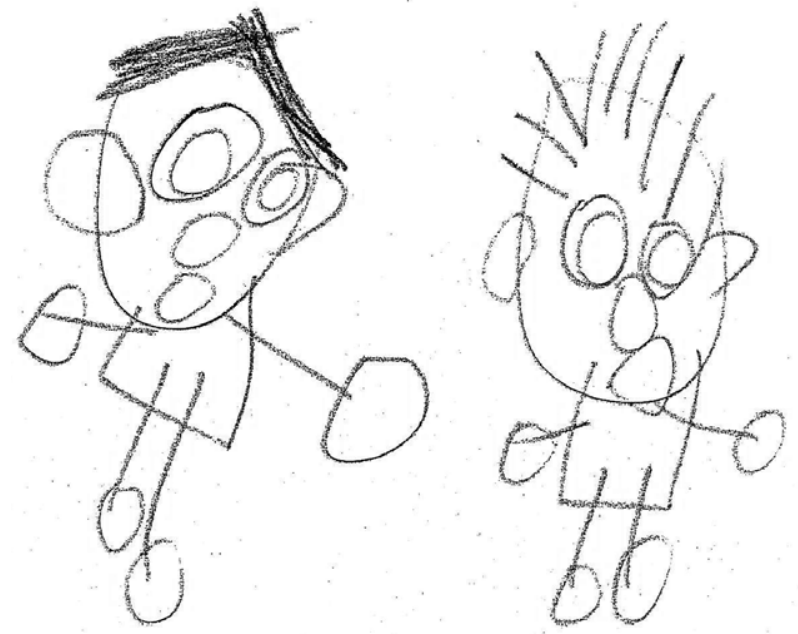

図49歳 8 ケ月時に描いた人物画

捕まえようとしてどんどん沖へ行ってしまう。

$10: 3$ 。毎週スノーボードに行っている。インス トラクターにおじけずに打ちとけている。相手の顔 を見て行動するようになった。学校では他の子を追 い回す。一時期スクールバスの中で喧嘩をして困っ たことがあるが, 最近は人のこころが読めるように なってきた。祖父がダメッ!というとニヤニヤして いる。精米機の音にもなれてきた。

$10: 6$ 。友達に関心が出てきたものの関わり方を 知らない。アスレチックの水遊びを見ていて，水か けっこをしていた。寄宿舎では何々をしなければい けないといった規則に従えるようになってきた。最 近は絵を描くよりも文字を書くようになり，文字で 意味が取れ始めている。トイレの水洗音も嫌がらな くなり, 聴覚過敏症から脱却した。

$10: 10$ 。ことばによる指示が分かるようになって きた反面，都合が悪くなるとCI を外す。CIを外し たときはコミュニケーションは手話。宿題には自ら 取り組む。

$11: 4$ ○室の際母が「ぼうしをとって」という と脱帽した。今までより考えて行動する面がみえて きた。自分のことは自分でやりたがる。寄宿舎生活 の効果は大きいと感じるが, 聾学校の先生はこのこ とに気付いていないようだ。スキー場でリフトの乗 り降りは自分でする。

小学部 5 年を修了するに当たり, 担任から「色々 な経験を積み重ねてとても落ち着いて活動に参加す ることができるようになった。昨年のように帰りの
時間の間際に大泣きしてパニックになるようなこと は全くなくなった。日直の日は自分から進んで友達 の前に出て自信ある態度で会を進行している。本当 に上級生のお兄さんらしくなったと感じている。友 達と関わりたい気持ちから，髪の毛を引っ張った り，追いかけたりする行動はほとんど落ち着いた。 3 学期からスクールバス乗車を再開したが，大きな 問題はないようだ。やや騒がしい休み時間のときな ど, 教室で $5 \mathrm{~m}$ 位離れた距離から名前を少し大きめ の声で呼びかけると確実に振り向く。隣の教室で大 きな音や声が聞こえると，気になって見に行こうと する。注意媣く音を聴いているようだ。 2 学期から 始まった顔などを連続して吒く行為は，大分少なく なったがまだ時折見られる。という報告を頂い た。

$11: 7$ 。小学部 6 年生。寄宿舎では 2 年下に気の 合う子がいて面倒をみている。両親は担任や寄宿舎 の先生と連絡帳なども活用し合って親密な関係を保 ちながら教育を進めている。マイペースな面は残っ ているが，落ち着いて本をよくみるようになった。

$11: 10$ 。異性に対する意識が芽生えてきたよう で，車の中で $\mathrm{AKB} 48$ の CD をかけると，特定の歌 手の曲にとたんにリズムを取り始め, 雑誌に AKB48 の写真が載っていると, その人を必ず指差す。道順 に対するこだわりはなくなった。聾学校では文字を 介して「はい」「いいえ」の判断学習（例えば，柿 の絵に対して，「これはみかんですか」には「いい え」に○,「はい」にメをつける）ができるのに対 して用途の質問はまだ理解できないとのこと。

\section{総括並びに考察}

本児の難聴は当初比較的軽いと考えられたが，1 歳になって難聴は進行し始め, 3 歳 9 力月頃には補 聴器の効果もほとんど認められなくなったため， 3 歳11ヶ月時に左耳にCI を装着させた。本児には重 い知的障碍や ASD もあり, CI の適応にすべきか異 論もあったが，コミュニケーションの改善に役立つ だけでも有意義と考えて CI装着に踏み切った。本 児の今日までの発達経過をまとめると概略図 5 の如 くになる。

すなわち， 1 歳 6 力月頃つたい歩きが始まったが 自己中心的行動が目立つようになり，2歳になって 


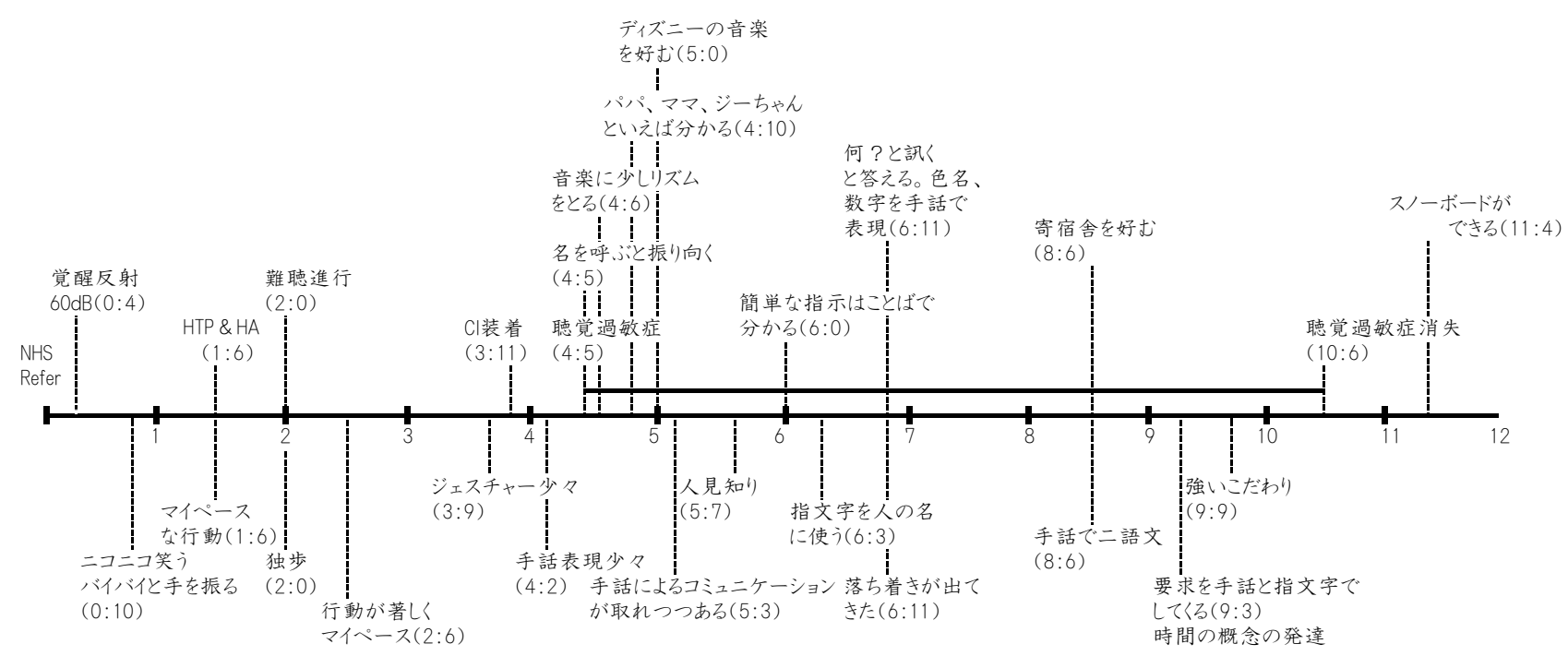

図 5 本児の全体的発達経過の概要

独歩が可能になると, 制止のきかない, 落ち着きの ない行動が一段と目立ってきた。7歳に近付くと若 干落着きは出てきたものの, マイペースな行動や, 手にしたものをヒラヒラ常同的に振る，特定のもの にこだわるといった ASD に見られる行動特性は現 在も続いている。本児には当初からジェスチャーや 手話なども使ってコミュニケーションや言語指導を

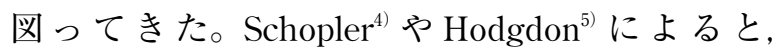
ASD 児の多くは聴覚的情報処理能力に比して視覚 空間的処理能力の方が高い。しかし本児では CI 装 着後半年位して名前を呼ぶと振り向くようになり， 音楽にもリズムを取って反応する傾向が出てきた。 現在 CIがことばの理解や音楽を楽しむ上でも役立 っていることに疑いはないが，言語表出はもっぱら 手話に頼っている。これは現在では自動化された状 態であり，本児が知的障碍児であることを考えると この状態を今後も受け入れていきたい。手話による 言語指導は言語発達のみならず，ことばの聴覚的理 解や環境音並びに音楽の認知にも役立っているが, この点は筆者のトップダウン処理の原理 ${ }^{6)}$ で説明で きる。しかし一方ではトイレの水洗音を嫌う $(4: 5)$ といった聴覚過敏症が出現し，一時 CI 装着を拒否 する傾向も出てきた。聴覚過敏症は10歳半頃には消 失し, 現在 CI は常用できている。聴覚過敏症は $\mathrm{ASD}$ の子どもに比較的多くみられ，これが原因で CI 装用不可能に至った例7)があっただけに油断で きない。

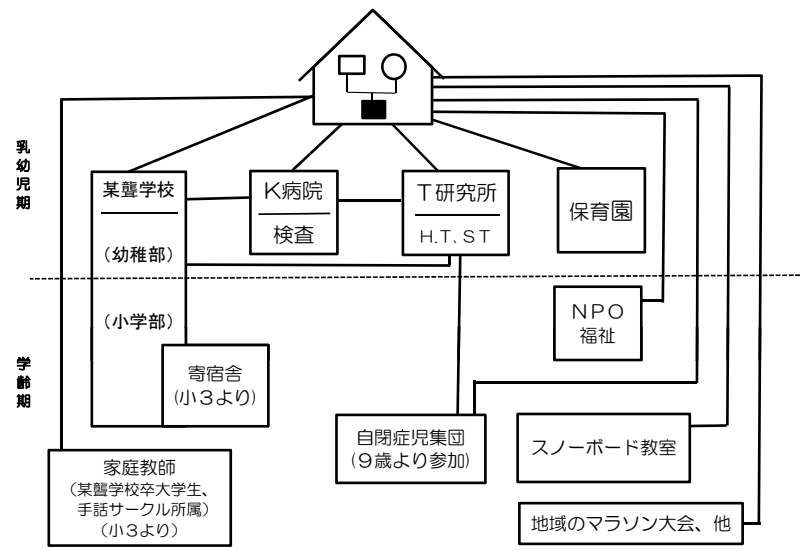

図6 本児の療育及び家族を支援してきた諸機関及び人と の関係

言語発達に関しては，6歳に達する頃から簡単な ことばによる指示が分かるようになり， 7 歳に近付 くと「これ何？」の質問に手話で答えるようになっ た。コミュニケーション面では, 3 歳 9 カ月頃ジェ スチャーを少し使うようになり，5歳 3 力月頃には 手話も交えるようになった。6 歳 3 力月頃になる と，人の名前を最初の一文字を指文字で表わすまで になった。

両親は図 6 に示したように, 龍学校及び寄宿舎の ほか, 努めて学校以外の $\mathrm{NPO}$ 施設, $\mathrm{S}$ クラブ, 自 閉症の集団, 壟の家庭教師，更には地域のマラソン 大会，スノーボードなど生活体験の場を広く求め て，いろいろな分野の人や子どもとの交流並びに社 会的体験を豊かに積ませてきたが，その結果小学部 
5 年時の担任の評価（11:4）にもみる如く, 情緒 も安定し，人間的にも豊かに育ってきたという感を 深くする。

ASD 览の療育に関しては, Schopler ${ }^{4)}$ が TEACCH プログラムを提唱し，わが国では佐々木 ${ }^{8)}$ がこれを 導入して実践と研究を広めてきた。このプログラム は ASD 児 (者)とその家族を支援する制度の開発, 整備などにわたる実践研究から構築されていて，こ こでは「自閉症の文化」や「構造化された指導」が 基本理念をなす ${ }^{4)}$ 。佐々木 ${ }^{8)}$ によれば，自閉症の人 は自閉症のままできるだけ自立的な活動をしながら 我々一般の人間とどのように共生して生きるかを命 題として追求する。このインクルージョンの哲学に は筆者も大いに共鳴するところであり, 我々が本児 の発達支援に当って意四したところもまさにこの点 にある。本児が聴覚過敏症によるCI 拒否の危機を 乗り越え得たのも，このような背景があった結果と も考えられる。

ところで, 最近はいわゆる「発達障害」が増加し た9)といわれる。事実筆者の外来を訪れるコミュニ ケーション障碍児や聴覚障碍児をみても「発達障 害」に類する，または合併する子どもが増加したと いう印象を受ける。今回の報告例はASD に加えて 重い難聴と知的障碍を伴う重複障碍児であるが，い ずれにせよ，これらの子どもを診るにつけ，小児難 聴を標榜する外来は単に難聴診断だけではすまされ なくなっていることを痛感する。

\section{まと め}

NHS で難聴が疑われ, 難聴進行により 3 歳11カ 月時に CI を装着させた ASD 及び重度知的障碍を伴 う難聴児の12歳までの経過を報告した。

我々が本児の発達支援に当って重視してきたこと は, 親子のコミュニケーションと情緒の安定であ り, 乳児期は五感を介してこれができるものの, 歩 行が可能になるとコミュニケーションは聴覚や視覚 に頼る面が大きくなるだけに，HA や CIに期待す るところは大きい。本児の場合は難聴及び知的発達 の遅れに加えて ASD があり, これ自体もコミュニ ケーション障碍の要因をなしていると考えて, 対人 関係ないし社会性を育てるために䆍学校の集団や寄 宿舎，更には自閉症児のグループのみならず，保育
園のような健聴児の集団への参加にも配慮してき た。

CIに関しては, 聴覚過敏症のため一時装用を拒 否する時期があったが, その後聴覚過敏症が克服さ れるに及んで CI は常用できている。

これまでの本児の発達経過を顧みて, ASD の行 動特性は本質的に変わっていないものの, 対人関係 は改善しつつある。コミュニケーションは，本児は 手話中心であるが，聴覚を介しての言語理解は本児 なりに発達してきており，CI はコミュニケーショ ンはもちろん言語習得にも役立っている。ここに至 るまでには両親の熱意もさることながら，この家族 を支援してきた地域の関係機関及び人との交流や協 力の意義も見過ごすわけにはいかない。これらの支 援がなければ CI 活用に至らなかった恐れもある。

\section{Development of a deaf child with severe mental retardation and autism spectrum disorder who received cochlear implanta- tion in early childhood}

Yoshisato Tanaka ${ }^{12)}$, Satoko Ashino ${ }^{1)}$, Yumi Koyama $^{3)}$, Yuko Yoshida ${ }^{1)}$, Shigeko Harigai ${ }^{2}$, Kozo Kumakawa ${ }^{4)}$, Hidehiko Takeda ${ }^{4}$

\footnotetext{
${ }^{1)}$ Tanaka Yoshisato Institute of Education

${ }^{2)}$ Kamio Memorial Hospital

${ }^{3}$ Kenkokai Sogo Tokyo Hospital

${ }^{4)}$ Department of Otolaryngology, Toranomon Hospital
}

The patient is a 12-year-old boy who was suspected as having bilateral hearing loss at the newborn hearing screening. He was subsequently confirmed to have moderate hearing loss by behavioral and auditory brain stem response audiometry.

After participating in our home training program where he was given hearing aids, he was referred to a school for the deaf. He received language education by means of an auditory-oral method combined with manual communication, including gestures and sign language. When he was 
three years and eleven months old, he received a cochlear implant for the left ear, because of extreme deterioration of the hearing loss. Six months later, he began to complain of hyperacusis to noise from a hair dryer, flushing of the toilet, etc. He refused to use his cochlear implant because of the hyperacusis, but fortunately, this crisis was overcome when he became 10 years old.

He began to walk alone at the age of one year and six months, but showed restless behavior and began to show difficulties in forming interpersonal relationships, as well as avoidance of eye contact. When he reached the age of six years, he began to acquire language by the use of hearing and sign language.

Currently, he is acquiring social skills with the support of many people including our staff, deaf students who had graduated from the same school for the deaf, teachers for autistic children, instructors of winter sports, etc. He can understand spoken words through his cochlear implant, although his expressions are mainly by means of sign language.

\section{文献}

1 ) Argas MF : 非言語コミュニケーション。石丸 正訳, 新潮社, 東京, 1987, P15

2 ) Montessori M : モンテッソリー・メソッド。 阿部真美子, 白川容子訳, 明治図書, 東京, 1974, P34

3) 田中美郷, 進藤美津子, 加我君孝, 他 : 乳児の 聴覚発達検査とその臨床および難聴児早期スクリ ーニングへの応用。Audiology Japan 21：52-73, 1978
4) Mesibov GB, Shea V, Schopler E: 自閉症スペ クトラム障害の人へのトータルアプローチ $\mathrm{TEACCH}$ とは何か。服巻智子, 服巻繁訳, エン パワメント研究所, 東京, 2007

5) Hodgdon LA：自閉症スペクトラムと問題行 動一視覚的支援による解決一。門真一郎，長倉い のり訳，星和書店，東京， 2009

6 ）田中美郷，芦野聡子，小山由美，他：我々の臨 床における幼児人工内耳適応の考え方と療育指導 の方法論について。Audiology Japan 49: 178183, 2006

7 ）田中美郷，芦野聡子，小山由美，他：人工内耳 装用児に見られた聴覚過敏症について。音声言語 医学 52: 360-365, 2011

$8 ）$ 佐々木正美監修，小林信篤編著：TEACCH プ ログラムによる日本の自閉症療育。学習研究社, 東京, 2008，P.14

9）岡田尊司: 発達障害と呼ばないで。幻冬新書 267, 幻冬舎, 東京, 2012

10) Kaga K, Tanaka Y: Auditory brainstem response and behavioral audiometry, Arch. Otolaryngol 106 : 564-566, 1980

（2012年12月28日受稿 2013年2月7日受理）

別冊請求先： 个154-0021

東京都世田谷区豪徳寺1-32-8

田中美郷教育研究所

田中美郷

Yoshisato Tanaka

Tanaka Yoshisato Institute of Education

32-8, Gohtokuji 1-chome, Setagayaku, Tokyo, 154-0021, Japan 